\title{
Indium In 111 Anti-EGFR Monoclonal Antibody ABT-806
}

National Cancer Institute

\section{Source}

National Cancer Institute. Indium In 111 Anti-EGFR Monoclonal Antibody ABT-806. NCI

Thesaurus. Code C99169.

A radioimmunoconjug ate composed of a humanized monoclonal antibody Ig G1 directed against the epidermal growth factor receptor (EGFR) and labeled with the radio isotope indium In 111, with potential radioimaging activity. Indium In 111 anti-EGFR monoclonal antibody ABT-806 binds to a specific epitope of either wild-type or EGFR variant III mutant on tumor cells, thereby allowing imaging of EGFR-expressing tumor cells using gamma scintigraphy. ABT-806 is the humanized version derived from the predecessor chimeric monoclonal antibody 806. EGFR, a receptor tyrosine kinase overexpressed on the cell surfaces of many tumor cell types, plays a key role in tumor cell proliferation. 